\title{
ЦАР ЕДІП: МІФ ПРО РАЦІОНАЛЬНІСТЬ
}

\author{
Г.А. Балута \\ И загадок разрешитель, и могуще- \\ ственный царь. \\ Софокл, «Царъ Эдип»
}

\begin{abstract}
Філософська думка сучасності диктується соціальними питаннями i проблемами, трансформуючись у практичний зміст, залишаючись при цьому найбільш актуальним і досконалим знанням. Смислові проблеми, поставлені несподіваними поворотами буття, вимагають аналізу найбільш цінних і вартих філософської уваги інтелектуальних та практичних пріоритетів, втрачених на шляху культурної історії людства. Все більшого значення набуває звільнення думки від тенденційних нашарувань, звернення до настанов традиційного і релігійного знання. У намаганні неупередженого поєднання найбільш цінних фрагментів духовної історії, філософський аналіз здебільшого розгортається у площині регулятивного застосування знання, узгодженості системи знань із загальними законами мислення. Припущення внутрішніх законів необхідним принципом, що об'єднує природні закони та закони духовного порядку, дозволяє оцінити ситуацію, уникнувши їі поверхневої оцінки. Формування внутрішніх очікувань, надання їм сенсу, логіка суб'єктивної дії включені у сферу духовності як рівня людської досконалості. Граничне обгрунтування норм людської дії, загальна їх значущість віддзеркалюються у питаннях про основу свободи як безумовної належності, спрямованості свободної дії, етичного вдосконалення суспільства. Аналіз раціональних мотивів людської діяльності, що поширюється і у етиці, зумовлений принципово новим її характером, поступово виходить за межі класичних етик. Реальність мислення, ціннісна криза, глобальні процеси виявили суперечності між приватними етиками і культурними стандартами. Розгортається проблема цивілізаційного взаємовпливу та його епіфеноменальних наслідків
\end{abstract}

Актуальні проблеми духовності

(Відп. ред.: Я.В. Шрамко)

Кривий Ріг (2005), 347-355 
у результаті раціональної дії. Декларація раціональності, здобута зусиллями логічної аргументації, в тому числі і у формах життєвої практики стала само собою зрозумілою аксіомою. Однак, чи зможе людина як свободний від вільного примусу суб'єкт, у своїх діях спиратися на «чисті» раціональні цінності? Чи може раціональність як така виступати у якості цінності, зокрема повсякденно-практичної? Позначена філософським оптимізмом, практична філософія К.-О.Апеля та Ю.Хабермаса все ж обгрунтовує раціональність етичних норм, як основи колективного порозуміння, на жаль, мало наближає до реалій повсякдення.

Входження України в європейський цивілізаційний простір, вимагає розгляду окремих аспектів західного і східнослов'янського міжцивілізаційного діалогу, позначеного відмінностями етичних систем та ціннісних ідей у плані раціональності. Це спонукає до пошуку оптимальних смислових орієнтирів, що скерували б цивілізаційну динаміку у позитивне русло, стаючи на заваді міжцивілізаційної асиміляції та інших негативних явищ, у сутності яких генералізується раціональне мислення. Західний цивілізаційний генотип позначений специфічними особливостями, серед яких «раціональність» $\epsilon$ помітною культурною рисою, втіленою, зокрема, в елементах католицької і протестантської християнської парадигми. Саме на Заході виникли явища культури, що отримали універсальний зміст. Західна філософія будувалась не на внутрішньо-особистісному, а на зовнішньому предметному горизонті. Раціональність як спроба не безпосереднього, а інтелектуально-логічного впорядкування світу, виявилась малоз'ясованим у своїй суті явищем, хоч і мала свою проекцію у всі сфери буття. Чи не почалася раціональна еволюція з часів Адама і Єви - одна 3 найбільш відомих людству історій? Гріхопадіння людини - перший раціональний факт. Відчувши внутрішній сумнів, Єва зриває плід і відкриває очі у інший світ, все більше віддаляючись від внутрішньої божественної суті. Допитливість і зухвалість переказувалась давньогрецьким міфом як фатальна пристрасть. Раціональність - лабіринт Мінотавра, що поглинає сміливців. Поступово відбувається інтелектуальна революція, що мала своїх прометеїв: мислення у межах міфу вдосконалюється Логосом - все осягається розумом людини.

Світ Біблії як Слова Істини, безпосередньо явленого пророкам, витлумачується смертними. Так виникає Логос, що відновлює ідеї античності. Логос - це порядок, гармонія, розум. Дозволивши розуму стати богорівним, людина і сама стає богорівною. Людські можливості: надія і відчай зійшлися у фокусі «раціо».

Слов'янська метакультура вибудовується на дещо іншому грунті, звертаючись здебільшого до цінностей християнського містицизму, боячись інтелектуалізму і засуджуючи раціональну думку. Православна церква назавжди відокремила раціональне знання від віри як закону внутрі- 
шньої переконаності. Якщо істина відкрита у Божественному слові, тоді гріх сумніватися у ній, зраджуючи розум і серце. Одкровення є основою істинного знання. У розумінні В. Соловйова: «Одкровення - проявлення Вищої Сутності у нашому світі, з метою повідомити нам більш-менш повну істину про себе і про те, що вона від нас вимагає. У О. зміщуються, таким чином: 1) факт богоявлення (теофанії), шляхом якого відкривається нам Божество, і 2) релігійно-моральний зміст цього факту, тобто те, що в ньому відкривається. Присутністю першого елемента О. відрізняється від суто людських вчень і систем, а присутністю другого - від тих ірраціональних проявів мислимих божественних чи демонічних сил, якими сповнена історія всіх релігій»[5, с. 345-346].

Духовні основи слов'янства формувалися на основі історико-культурної ситуації, що забезпечила унікальне сплетіння Візантії і Риму. Геополітичне розташування, світоглядна толерантність втілилися у східному кордоцентризмі, що не має аналогій ні у західноєвропейській, ні у власне східній парадигмі мислення. Світ трансцендентного відкривається людині не через дію чи ініціативу, а через внутрішнє самозаглиблення як особисте одкровення, що у контексті історії пророків не має відмежування змісту одкровення від загальнолюдської мети. Г. Сковорода, П. Юркевич визначили умовою істинного розуму його укоріненість у внутрішній єдності Серця. Інтелект змусив не переживати світ, а прагнути його логічної довершеності і демістифікації. Істина стає прагматичною реальністю, орієнтуючу у напрямку пошуку доцільного. Асоціація раціонального як доцільного вже мало у кого викликає сумнів. Але ж наскільки цей усталений зв'язок є практично виправданим? Розглянемо це виразніше.

Епістемологічні ідеї Канта здивували людство своєю фантастичністю: «світ має вартість його творця». Об'єкт репрезентується мисленням через сприйняття. Кантівський висновок сформулювався як відповідь ідеям Юма, за яким знання про світ на основі досвіду не може бути достовірним. Виключення складає пізнання взаємозв'язку між поняттями, яке все ж не відповідає основному онтологічному запиту. Так само, за Юмом, невірогідним є і факт взаємозв'язку етики і епістемології. «Кант оцінив скептичний емпіризм Юма як скандал у філософії: Юм вибиває основи і з-під етики і з-під природничих наук. Кант ставить перед собою завдання довести, що всередині етики і всередині природничих наук $є$ те, що ми за допомогою нашого розуму можемо обгрунтувати у якості строгого і загальнозначимого» [4, с. 442-443]. За Кантом, впорядкування світу $€$ компетенцією самого суб'єкта. Світ як феноменальна реальність вибудовується за межами інтерсуб'єктивного як важливого фактора буття свідомості. Кант не повертається до ідей класичного раціоналізму, представлених Декартом. Розглядаючи раціоналізм як псевдонауку, але не заперечуючи нормативну функцію раціо на прикладі математики і приро- 
дознавства, Кант зосереджує увагу на суб'єкті як епістемологічній умові можливості знання. Кантівська критика епістемологічного скептицизму перегукується також і з критикою скепсису етичної нормативності, яка 3 новою та небаченою раніше інтелектуальною гостротою, відновиться у ніцшеанстві. Грандіозна спроба піднесення над добром і злом перетворила мораль на практичну мету. Випереджаючи З. Фрейда, Ф. Ніцше інтерпретує мораль зі спостережливістю психоаналітика. Раціоналізуючи істину як рід заблудження, філософ не заперечує її життєво-практичної вартості. Хаос світу не має відповідності, 一 визнає Ф. Ніцше, однак, поставлена під сумнів класична відповідність між мислимим і дійсним, проступає у відповідності між мислимим і корисним (людським). Метафізичну істину було скасовано: істина виявилася мисленим конструктом практичної потреби.

Епістемологічний та ціннісний скептицизм, заперечення моральної онтології поляризували ідеї Ф. Ніцше та І. Канта, однак, взаємоперетин протилежних аргументів все ж виявився на межі аналізу суб'єкта як передумови впорядковуючої здатності та аргументації стосовно буттєвої необхідності істини. Відповідність чи розуміння такої відповідності виявилося необхідною психологічною потребою. Раціональність (потреба відповідності) не виштовхується за межі досвіду. Заперечуючи відповідність, ми знову намагаємося впорядкувати світ, хоча й іншим чином. У відзнятому вигляді можна розкрити логіку пізнання шляхом взаємовідтворення двох операцій: сумніву та його вирішення: відповідності, які розглядаються нами як раціонально-психологічні. Відоме гасло раціоналізму «мислю, отже, існую» не у повній мірі виступає очевидністю. Обравши сумнів у якості методу, Декарт виключає всі твердження, які не можуть виступати постулатами дедуктивної філософської системи. За відсутністю достовірної системи відліку, ми сумніваємося у всіх чуттєвих враженнях, переходячи у нескінченність емпіричних перевірок. Бездоганність логіки передбачає досконалість мислення і це підлягає сумніву також. Сумнів у чуттєвому і логічному замикається на безпредметному інтелектуальному зусиллі, який не скасовується як інтенційність. Отже сумнів передбачає осмислену спрямованість свідомості можливою за умови розуміння, що передбачає існування. Переживання існування відтворюється як творення смислу, внутрішньої форми предметного змісту.

Допредметна укоріненість єдності буття і мислення суб'єкта фіксується «розумінням»: відповідності внутрішнього зовнішньому. Філософські системи $\Phi$. Ніцше та I. Канта, переглянувши зв'язок між мислимим і дійсним, знову підійшли до класичної епістемологічної проблеми. Не маючи достовірної вказівки на справжню конфігурацію реальності, ми зміщуємо буттєву реальність 3 реальністю нашого знання, яке може мати суб'єктивну чи інтерсуб'єктивну смислову форму, чого недостатньо 
для впевненості у достовірності. Так, ця проблема розглядається Декартом метафізично: наше уявлення досконалості безвідносно знання у його власному понятті, дає вказівку на існування такої досконалості, що перевищує власне людське. Досконалість передбачає абсолютну достовірність знання, людина наділена лише уявленням такої досконалості (відповідності усіх речей їх змісту), людині властиві сумніви та невизначеності. Досконале знання повинне виключати сумнів, отже, людське знання у принципі не може бути досконалим. Як наслідок, воно міститься у причині, яка своєю ємністю включає сумнів, - міркує Декарт. Отже, існує досконала причина досконалого знання. Все подібне, що є настільки очевидним, наскільки є очевидною наша здібність до мислення, може визнаватися як достовірне. Помилки ж виникають не від розуму, а від вільної волі, вони неминучі у ході нашого пізнання, і це $\epsilon$ часткою Божественного плану, вважає філософ, визнаючи людську недосконалість невідомою нам умовою таємної гармонії світу. Таке протиставлення розуму і волі набуває характеру внутрішньої суперечності, переплетінням душі і тіла у дуалістичному існуванні протяжності і душі, свободної і раціональної. Простота і виразність декартової методології, дозволяє нам поглянути на проблему очевидного з пересічної точки зору, не підриваючи достовірність буття сумнівом.

Східна філософія, з її несподіваною логікою, розгортає думку у трохи протилежному руслі. Нова методологія, напрацьована східним мисленням діаметрально протилежна західному дуалізму. «Мислення є буття» - інтелектуальна формула, яка зорієнтувала Європу, легко читається і обернено: «Буття є мислення». «Коли людина промовляє «я єсть», вона вже думає. Вона не може стверджувати свого існування, не звертаючись до процесу мислення. Мислення передує буттю, але як може людина думати, якщо її нема? Буття повинно передувати мисленню», - стверджує Судзукі $[2$, с. 371-372]. Життя виявляється простим фактом, не потребуючим ніякого прояснення. Східний образ думки активно заперечує подрібнення і аналіз, що розкладають єдність світу. Роздвоєння реальності-це робота розуму; фактично - це шлях, йдучи яким, ми намагаємося зрозуміти $\dddot{1}$, щоб використовувати у повсякденному житті. Але таким шляхом ми не зможемо досягти розуміння реальності. Роздвоєння допомагає нам прийти у прагматичний контакт з реальністю, але це не торкає наших глибинних інтересів. «Для задоволення останніх реальність повинна бути осягненою у безпосередньому переживанні» [2, с. 544-545].

Факт мислення означає факт буття, єдності мислення і безпосереднього враження, складаючих контекст «життєвого світу». Відчуваючи біль, ми переконані у його реальності, не плутаючи відчуття нашого болю з радістю чи відчуттям іншого суб'єкта і надаючи ситуації достовірної осмисленості. Перебуваючи у повсякденності, ми не розчиняємо реальність по- 
за межею «я існую». Ми не фіксуємо факт такого знання сумнівом, вступаючи у магічне коло нескінченного скепсису, коли факт нашого знання знову стає незнанням, яке у результаті пізнавальної активності врештірешт знову стає знанням. Просуваючись у часі шляхом розтину реальності межами простору і часу, все глибше проникаючи у сутність явищ, людина тим самим впритул підійшла до можливих наслідків «парадоксу раціональності», визначеного М.Вебером. Вона потрапила у пастку системи, створеною нею ж самою. «Оволодіння» реальністю, перетворення її у інтенсивному напрямі поступово стає «вбивчою силою», переструктуруванням свідомості за непередбачуваним вектором. У пошуках «втраченого», людство відновлює духовність ї мораль, оминаючи забуті стежки повсякденного знання. Геніальний задум Сократа поглянути у світ з іншої висоти, змусив шукати таємницю буття у людині.

То що ж побачила людина у глибині власної Персони? «Приналежність духу»? «Прив'язаність до матеріального?» Безтілесний дух не успадковує тіло і пориває зі світом: керований тілом дух, втрачає справжню свободу у трансформаціях інтелекту. Які варіанти цього конфлікту раціонально добирає людство, геніально виправдовуючи себе? «Раціоналізація - знаходження правдоподібних причин для виправдання дій, викликаних пригніченими неприйнятними почуттями. Реалізовані засоби: дискредитація мети (елементарне обезцінювання недосяжного); дискредитація значущого іншого ...; перебільшення ролі обставин, долі; ствердження шкоди як блага; переоцінка цінностей, всієї мотиваційної системи; самодискредитація (спокута провини)» [1, с.346]. Зазираючи у себе, чи побачила людина щось нове, чого б іще не була варта: Заратустра i Фауст, царівна Касандра і цар Едіп, вічно закоханий Нарцис. .. Відкриття глибинної психології персоніфікували людину, розкраяли її душу на окремі визначення. Любов, обернена проти світу, перетворилася у любов до себе. «Людина може як завгодно далеко розширяти власне пізнання, може видаватися собі скільки завгодно об'єктивною, але єдиний її прибуток із усього цього $є$ тільки їі власна біографія»,- напише $\Phi$. Ніцше $[3$, c. 65]. Нарцисична заглибленість розвиває симптоми «творчої хвороби», визначає А.-Ф.Еленбергер. «Виклавши основні ознаки творчої хвороби, Еленбергер переходить до огляду її різних проявів у історії людської культури. Носіями цієї аристократичної хвороби, на його думку, можуть уважатися численні релігійні містики, літератори і філософи (з Фрідріхом Ніцше на чолі), але найбільш виразні приклади він знаходить у «творчих хворобах» Фрейда і Юнга, а також у релігійному житті примітивних народів» [3, с. 69].

Надто відверті новації психоаналізу і глибинної психології виокремились у вельми колоритну науку - раціональну психологію, розбудовану на основі асоціативної аналогії у якості провідної $\mathrm{i}$ «достовірної» методо- 
логічної установки. «Буття-у-світі» є буттям особистого Я, закатованого власним чи набутим від активного спілкування «неврозом». Але людина все ж стає все більш «психологічною», знаючи, що́ можна у собі угледіти і як це виправити. Раціональна «переоцінка цінностей» призвела до зростання автономії по відношенню до встановлених традицією норм і соціального порядку. «Поява подібної культурної території, названої «особистим психологічним життям», і визначило успіх психоаналізу, що першим висунув зв'язну теорію про те, що належить робити з власною душею, коли релігійні і батьківські авторитети не є істиною у останній інстанції»,відзначає В. Менжулін [3, с. 104].

Дані соціологічного аналізу пов'язують небачений розквіт психології із занепадом релігії: «майбутньої ілюзії людства», генетично успадкованого неврозу. Психологія стає крипторелігією західного світу, підірвавши основи християнської віри. Психоаналітична біографія К.Г.Юнга висвітлює глибоку внутрішню драму: саме у понятті індивідуації філософу вдалося асимілювати безмежний міфо-символічний матеріал, викликаний інфляцією особистості як потребою нарцисичної грандіозності. (Така проективність позначилася на специфіці релігійного світосприйняття: філософ не довіряв релігії, так само як і З.Фрейд.) Відкриття З. Фрейдом «психічної енергії», опис дії захисних психологічних механізмів, Ерос і Танатос пізнього Фрейда, що можна розглядати як внутрішній дисонанс, дозволяють констатувати аналогії з ідеями Декарта, за яким «пристрасті душі» виникають внаслідок зовнішньої дії. Поставивши проблему розумності існування, психоаналіз виступив контраверзою філософії Декарта, однак, таке протистояння мало спільну епістемологічну установку «шлях сумніву» у достовірності сущого. Якщо явлений світ є для мене сумнівним як є сумнівним Бог і я сам, чи не означає це певної втрати? Скажімо, втрати відповідності самому нашому «я» i, таким чином, світу. Розуміння як формальна умова смислового вибору має передбачати різну смисловпорядковуючу процедурність: шлях сумніву і критики, шлях віри і релігії, шлях екзистенції як переживання світу. Ясність, яка є метою інтелектуального пошуку, отримується нами у останньому з випадків, попередньо ми маємо справу зі складними випадками наукової і релігійної вір, позначуваних виходом за межу інтерсуб'єктивно-екзистенціальної єдності. «Віра означає визнання чогось істинним з такою рішучістю, яка перевищує силу зовнішніх фактичних і формально-логічних доведень. Це не означає, що істини віри не підлягають ніяким доведенням, а значить тільки, що сила віри залежить від самостійного психічного акту, який не визначається цілковито емпіричними і логічними підставами», - вважає В. Соловйов [5, с.25]. Сила прагматичного спостереження як інтенційність волі звужує горизонти свідомості, одкровення - «доля обраних»повідомляє нам більше того, що утримується в інтерсуб'єктивних чуттє- 
вих і логічних даних. Ми безумовно віримо у існування світу, незалежно від даних експерименту чи моделей «внутрішнього Я» зразків духовних глибин і сумнів у ньому можна мислити фактом «захоплення свідомістю власної природи». Віра у достовірність буття $є$ первинною по відношенню до знання чи мислення, безвідносно до їх достовірності. За В. Соловйовим, віра у реальність світу має над-свідому укоріненість, вона $\epsilon$ вираженням у свідомості надсвідомого зв'язку суб'єкта з об'єктом. «Чим простіший, загальніший і неминучий цей зв'язок, тим сильніша відповідна йому віра. Так, всього найсильніше ми віримо у буття зовнішнього світу, тому що ця віра лише відображує у нашій свідомості той першопочатковий, простий i незаперечний факт, що ми, тобто даний суб'єкт, є частина загального буття, всесвітнього цілого. Так як цей факт передує всякому мисленню і пізнанню, то і визначувана ним віра не може бути видалена ніяким мисленим і пізнавальним процесом», - міркує філософ [5, с. 25]. Напрям такої думки дозволяє переглянути «достовірність» картезіанського висновку, отриманого у результаті редукції реальності. Адже сумнів як тип осмислення імпліцитно міститься у самій його можливості, тобто сумнів як і інші типи смислового впорядкування передбачає онтологічну укоріненість, поза якою «знання», незалежно від його достовірності, неможливо мислити. По-друге, ідеї I. Канта, після яких мало що може набувати вимірів філософської новизни, дозволяють припустити певну залежність між внутрішніми визначеннями об'єкта і мірою пізнавальної активності суб'єкта, типом приватної смислової реконструкції реальності. Тому теоретично достовірне знання передбачається за умови зняття інтенціональної напруги між суб'єктом та об'єктом. Мінімізацією такої ментально-дієвої активності $\epsilon$ наближення до природнього порядку речей, не збурюваного сумнівом односпрямованої смислової орієнтації спільноти, що у світлі кантіанської ідеї ноуменального світу здається практично-необхідним.

$\mathrm{y}$ такий спосіб ми намагалися підійти до ідеї «розуміння»-специфічного смислового впорядкування, що не зводиться до раціонального, але i не заперечує його, виступаючи формою компліментарності буття i мислення. Релігійна цілісність душі і світу, критикована Фрейдом як зразок антинаукової думки, $\epsilon$ предметом постійної мети православної етики; заборони роздвоєння душі на добро і зло, збереження душевного і духовного миру. Гармонія душі - це віра у реальність світу, відсутність «влади тіла», що прив'язує до світу та «влади духу», яка відкидає світ, вкладаючи його у форму раціональної чи ірраціональної системи. Достовірність буття фіксується як константа людської природи: межа між мислимим і дійсним, порушувана «інтенційною одержимістю» світом, ідеєю, еgо. У ракому разі людина забуває любов і Бога, у «котораго нет изменения и тени перемены» (Иак. 1.17.). У процесі руйнування «життєвого світу» виникає ситуація духовної розгубленості і, спочатку непомітної для людини, 
духовної втрати.

Інтенсивна прагматична установка свідомості та об'єктивована нею штучна реальність, процес соціальної диференціації підсилюють тенденцію деформації інтерсуб'єктивного «життєвого світу». Формування різних за своєю аксіологічною та культурною метою груп, активно діючих у одному цілераціональному напрямі, сприяє виникненню інтерсуб'єктивно-неузгоджених і непередбачених ситуацій. 3 іншого боку, проблема інтерсуб'єктивної раціональної етики вступає у суперечність з проблемою особистої свободи, яка обертається втратою її екзистенціальної потреби. Керований якнайкращими раціональними намірами, суб'єкт опиняється перед контр-фінальним результатом власних дій. Така перспектива «апелює до збереження» буттєвого змісту унікальності: особистого «розуміння» світу, що є буттям неупередженої «укоріненої» людини, незалежної від наукового об'єктивізму, колективної оцінки та матеріального примусу. Таким чином, смислова унікальність культур, так само як і неповторність свободної особистості у її особистому світорозумінні повинна бути передбачена внутрішньою метою метаісторії.

Згадаємо ж нещасного Едіпа, що не повернувся до Корінфу i, гнаний дією, перемагаючи Химеру незнання, зрячий просувався у темряві, злом платив за зло, а ставши сліпим, «прозрів», полишившись у віках ні в чому не винною «раціональною людиною».

\section{1 Бібліографія}

[1] Аниупов A.Я., Шипилов А.И. Конфликтология: Учебник для вузов. - 2-е изд., перераб. и доп. - М.: ЮНИТИ-ДАНА, 2004.

[2] Буддизм. Четыре благородных истины. - М.: ЭКСМО-Пресс; Харьков: Фолио, 2000.

[3] Менжулин В.И. Расколдовывая Юнга: от апологетики к критике. K.: Cфера, 2002.

[4] Скирбекк Г., Гилье Н. История философии: Учеб. пособие для студ. высш. учеб. заведений. - М.: ВЛАДОС, 2001.

[5] Философский словарь Владимира Соловьёва. - Ростов н/Д.: Феникс, 1997. 